\title{
Development from Outskirts: Analysis of Budgeting for Village Funds in Indonesia
}

\author{
Submitted 30/05/20. $1^{\text {st }}$ revision $21 / 07 / 20$, $2^{\text {nd }}$ revision $14 / 08 / 20$, accepted $30 / 09 / 20$
}

\author{
Marlan Hutahaean ${ }^{1}$, Johnson Pasaribu ${ }^{2}$
}

\begin{abstract}
:
Purpose: This article explains the governments' policy in village building, especially budgeting for village funding policy in Indonesia.

Approach/Methodology/Design: There were used two analyzing methods namely, the qualitative method and a public policy analysis. The qualitative method is used to describe in detail, both the primary and secondary data. Then, the public policy analysis method is used to analyze and describe the root causes of the emergence of the Village Fund's policies.

Findings: This research found that the Village Funds' policy has not accelerated the process of village development. Based on these findings, there are proposed the following policy recommendations: firstly, it is necessary to improve technical guidance related to program choice and budget formulation for the village apparatus. Secondly, there is a need for synergy between the village apparatus, private sector, and universities in conducting studies on village issues.

Practical Implications: The study will contribute positively to understanding the implementation of multi-level governance theory in village development in Indonesia.

Originality/Value: The study believes to contribute positively to the understanding of Village Funds for the acceleration of village development.
\end{abstract}

Keywords: Public policy, village development, village apparatus, program priority, budgeting.

Paper Type: Research article.

ISSN: 2241-4754, H index 10, Q3.

Acknowledgments: The authors would like to thank the Department of Master of Administrative Science, Department of Public Administration, Faculty of Social and Political Sciences, the University of HKBP Nommensen, that has funded this research.

\footnotetext{
${ }^{1}$ Department of Master of Administrative Science, University of HKBP Nommensen, marlan.hutahaean@uhn.ac.id;

${ }^{2}$ Department of Master of Administrative Science, University of HKBP Nommensen, pasaribu.johnson92@gmail.com;
} 


\section{Introduction}

This paper explains the villages' development policies, focusing on Village Fund (VF) policy. The study aims to analyze the implications of the VF policy on accelerating village development. It is believed that the VF policy has not been able to act as a channel for accelerating village development.

Development, including village development, is a process of change to a better situation. Village development, though, run by authorities and villagers' in Indonesia, did not completely and successfully achieve its goal, as many other factors influence it. Like every business, village development also has a risk of failure. This is in line with Bernstein (1996), Fafchamps, (1999b), as quoted by Anderson (2003), who said that development is an inherently risky business. Since the beginning of independence, the government has carried out various policies to help villages to develop, so their people do not urbanize. The various policies were carried out in one sector or multisectors, such as oil sprinkling policies in the Old Order era, Indonesian military entering villages and lagging villages in the New Order era, etc.

Unfortunately, these policies have not been able to help villages in Indonesia to progress and develop. The VF policy was established during the Reformation period. Through the availability of the village budget, it was expected to reach a better development level. The final implication of VF was to reduce poverty in the village. Unfortunately, village officials lack the ability to manage existing budgets and even bias their use. Several village apparatus elements punish the misuse of the budget. Village assistants who are specifically recruited to assist village officials in managing VF are neither very reliable. In fact, they often do not provide solutions but hinder the planning and implementation of the program. The main cause is their recruitment pattern, as facilitators managing VF are not chosen by competence, but rather on political nuances. In the early days of recruitment, those chosen as companions in the village were prioritized as affiliates or sympathizers of certain political parties. This is in line with Palmer (1984), as there are three problems when introducing and implementing programs in developing countries:

- technical staff and equipment;

- cultural background;

- politics;

\section{Methodology}

There were two methods used in analyzing data, a qualitative method, and a public policy analysis. The qualitative method is used to describe in detail the primary and secondary data. The public policy analysis method is then used to analyze and describe the root causes of the emergence of the Village Fund's policies, formulation, adoption, implementation, monitoring, and evaluation. The data used for analysis are primary data through interviews with resource persons from the regional apparatus; secondary 
data is obtained from books, previous research results, journals, online media, comments from relevant experts, bureaucrats, party elites, conference results, websites.

\section{Results and Discussions}

Village funds have been regulated in Government Regulation Number 60 of 2014 concerning Village Funds sourced from the National Budget. Article 1 paragraph (2) states that Village Funds are sourced from the State Budget of Revenues and Expenditures intended for Villages transferred through the District / City Regional Revenue and Expenditure Budget and used to finance government administration, development implementation, community development, and empowerment the community. Furthermore, in Article 6, it is stated that the Village Fund is transferred through the district/city APBD to be subsequently transferred to the Village APB.

Furthermore, the Ministry of Village, Development of Disadvantaged Regions, and Transmigration argue that the VF policy aims to change the village's paradigm from the one that has placed the village as the object of development into a village as a subject of development. Villages as objects of development mean that the government has a dominant role in directing its development. Conversely, the village as the subject of development is defined as the village itself with the community directing its development. Through such a paradigm change, it is expected that the village will be faster in development by involving community participation in the development process.

The government's changes not only at the paradigm level but also in terms of the development budget. Village development budgets have so far been integrated with the district budget, whose realization cannot be ascertained because depending on the district budget's priorities and capabilities, experience significant changes. As stipulated in Law No. 6 of 2014, Villages have their own budget, which is directly sourced from the State Budget (APBN), even though its distribution remains through the APBD.

After the issuance of Government Regulation No. 60 concerning Village Funds, from 2015-2018, VFs allocated through the APBN to tens of thousands of villages in Indonesia are as follows: in 2015, amounting to Rp. 20.67 trillion distributed to 74,093 villages, the average absorption capacity was 82, 72\%. In 2016, Rp. 46.98 trillion was distributed to 74,754 villages with an average absorption of $97.65 \%$. The year 2017 amounted to Rp. 60 trillion, distributed to 74,910 villages with an average absorption capacity of $98.26 \%$. In 2018 Rp. 60 trillion was distributed to 74,958 villages.

After running for three and a half years, the government claimed that the VF policy had gone well. Data in 2018 shows that VF, which was rolled out since 2015, has successfully implemented various programs, as shown in the following table. 
Table 1. Use of Village Fund Budget for Economic Support Programs2015-2017

\begin{tabular}{|c|l|r|}
\hline No. & \multicolumn{1}{|c|}{ Program Type } & \multicolumn{1}{c|}{ Amount } \\
\hline 1. & Development of Village Road & $123.145 \mathrm{Km}$ \\
\hline 2. & Development of Bridge & $791.258 \mathrm{M}$ \\
\hline 3. & Development of Village Market & $5.220 \mathrm{Unit}$ \\
\hline 4. & Development of Village Enterprises & $26.070 \mathrm{Unit}$ \\
\hline 5. & Development of Boat Mooring & $2.882 \mathrm{Unit}$ \\
\hline 6. & Development of Water Reservoir & 1.927 Unit \\
\hline 7. & Development of Irrigation & 28.091 Unit \\
\hline 8. & Development of Sport Facilities & 3.004 Unit \\
\hline
\end{tabular}

Source: Ministry of Village, Development of Disadvantaged Region and Transmigration.

In addition to development programs for economic support, programs carried out through AVF are related to programs to improve rural communities' quality of life. Table 2 below shows the success of the program.

Table. 2. Use of Village Fund Budget for Programs Improving the Quality of Life of Village Communities in 2015-2017

\begin{tabular}{|c|l|r|}
\hline No. & \multicolumn{1}{|c|}{ Program Type } & \multicolumn{1}{c|}{ Amount } \\
\hline 1. & Development of Ground Retainer & 65.918 Unit \\
\hline 2. & Development of Clean Water & 32.711 Unit \\
\hline 3. & Development of Toilet & 108.486 Unit \\
\hline 4. & Development of Maternity Center & 5.314 Unit \\
\hline 5. & Development of Drainage & $38.217 \mathrm{Km}$ \\
\hline 6. & Development of Early Chilhood Education & $18.072 \mathrm{Unit}$ \\
\hline 7. & Development of Integrated Health Service & 11.424 Unit \\
\hline 8. & Development of Well & 30.212 Unit \\
\hline
\end{tabular}

Source: Ministry of Village, Development of Disadvantaged Region and Transmigration.

In addition to development programs for economic support, programs carried out through AVF are indeed a recent study showing that the Village Fund's implementation can improve community welfare and change the village development paradigm because it encourages the relationship between state and village. The government claims there are two groupings of success of the AVF program, first, increased village status and poverty reduction yang shown through the alleviation of 9,975 disadvantage villages (IDM 2015-2016), exceeding the target of the 2015-2019 RPJMN of 5,000 villages and reducing the average number of poor people by $1.33 \%$.

Second, community welfare and economic growth has shown through the improved condition of road infrastructure $(81.9 \%)$, housing infrastructure $(27 \%)$, health services (43.9\%), education services (27.8\%), direct labor absorption (94.4\%), Village Enterprises' capital (30.8\%), increased community participation in $91.8 \%$ of villages and increased governance competence in $89.6 \%$ of villages and $75 \%$ direct employment, $50 \%$ of primary livelihoods and $33.3 \%$ business productivity increase. This success, according to the government, is also in line with the findings of the Gadjah Mada University Center for Rural and Regional Studies in North Kalimantan 
Province and 5 districts (Ponorogo, Bantul, Klaten, Sintang, and Sidoarjo). Community participation and the growth of social capital.

Furthermore, to accelerate the achievement of objectives, in 2018, the government changed the VF allocation pattern from before. VF in 2015-2017 is allocated for basic allocation (in the framework of justice) by $90 \%$ and $10 \%$ allocated based on the number of villagers $25 \%$, the ordinary poor people in the village $35 \%$, the village area $10 \%$, geographical location $30 \%$. As for VF in 2018, the allocation is for basic allocation (in the framework of justice) of $77 \%, 3 \%$ of affirmation allocations (deficient levels of backwardness and high poverty), and $20 \%$ allocated based on the village population of $10 \%$, the average poor in the village $50 \%$, village area $15 \%$, geographical location $25 \%$.

In addition to changes in VF allocations, in 2018, the government also made changes to budget use priority. According to Minister of Village's Regulation No. 19 the Year 2017 about Priority of Village Fund Utilization in 2018, "The Village Fund can be used for the implementation of programs/activities for village development, community empowerment, and inter-sectoral activities agreed through the village meeting then published in the public space."

Village Development for providing Basic Facilities, Village Economic Facility, Environmental Conservation, Natural Disaster Management. Meanwhile, Community Empowerment: Improving Quality of Basic Social Service Facilities, Local Resource Management, Productive Economic Business Management, Capacity Building for Disaster, Environmental Conservation, and Strengthening Democratic Village Governance. Whereas inter-sectoral activities related to supporting programs and activities such as Developing Village Flagship Products, Water Reservoirs, Village Enterprises (BUM Desa), or Holding BUM Desa and Sports Facilities.

Success claims presented by the government do not mean that VF policies do not experience problems. Various problems arise in the implementation of this VF policy. The Corruption Eradication Commission found at least 14 problems divided into four aspects. These four aspects are institutional regulation, aspects of governance, aspects of supervision, and human resources aspects.

Issues in institutional regulation can be seen from the incomplete regulations and technical guidelines for village finance implementation. Then, there is the potential for overlapping authority between the Ministry of Villages, Development of Disadvantaged Regions, and Transmigration with the Directorate General of Village Government Ministry of Home Affairs. Also, three ministries handle it, namely the Ministry of Home Affairs as the supervisor, the Ministry of Finance as the distributor of funds, and the Ministry of Village, Development of Disadvantaged Regions, and Transmigration as fund users. If one of the institutions experiences problems, it will certainly disrupt other institutions' work. For example, if the Ministry of Finance is 
late in channeling funds, the Ministry of Villages, Disadvantaged Regions, and Transmigration are hampered from utilizing funds.

The formula for distributing village funds as stipulated in Government Regulation No. 22 of 2015 is not transparent enough and is only based on equity. Then, the arrangement of fixed income distribution for the village apparatus from AVF as regulated in PP No. 43 of 2014 is less fair. Also, the obligation to prepare village accountability reports is inefficient due to regulatory provisions and overlapping. That means that village fund allocation cannot only focus on aspects of equity. The village needs one with another village that can be different, both in geography and the village's needs.

While from the management aspect, there are five issues: the time frame of village budget management sites is difficult to be followed by the village, the standard price unit of goods or services used as a reference for villages in preparing APBDesa is not yet available. The transparency of APBDesa's use and accountability plan is still low. Accountability reports made by the village have not followed standards and are prone to manipulation. Finally, the draft APBDesa does not fully describe the needs of the village.

Furthermore, from the aspect of supervision, there are three potential problems, such as the effectiveness of the regional inspectorate in supervising financial management in the village is still low, the public complaint channel is not managed properly by all regions, and the scope of the evaluation of the supervision carried out by the subdistrict head is unclear. Finally, from the aspect of human resources, there is a potential problem, that is, assisting personnel to have the potential to commit corruption because they exploit the weakness of village officials.

Another problem that should be of concern to the government is how in the process of preparing village programs synergizing the Village program (micro-level), with the Sub-District program (Meso level), and the District program (macro-level). The synergy of the three would certainly make village development more successful and targeted. So far, these three levels have not yet made synergies in program preparation. The proof is that there are programs that overlap between villages and districts, such as using a budget for the same job.

\section{Conclusion}

Village Fund Policy as stated in Law No. 6 of 2016 concerning Villages, which subsequently carried out through Government Regulation No. 60 of 2014 concerning Village Funds sourced from the State Budget, which was subsequently amended through Government Regulation No. 22 of 2015, has shown that the government has a high willingness to develop villages in Indonesia. Advancing the village means reducing poverty, which will thus improve its welfare. 
Planning and implementing village development programs using village funds is not an easy thing. That said because the village itself experiences the complexity of the problem. The lack of resource and equipment capabilities must become the government's main concern. The village fund program's focus should also be more directed to sectors that have been the source of life for villagers. The allocation of village funds to the agricultural and/or livestock sector should be improved rather than just the construction of road, bridge, sanitation infrastructure, etc. Indeed, infrastructure is important in supporting the entry and exit of commodities from the village. However, the allocation of village funds to strengthen the agricultural and/or livestock sectors, such as providing loans or subsidies, must be a top priority.

Furthermore, because community resources' ability is minimal in the village, besides the presence of village or sub-district facilitators, it is time to increase synergy between the government, universities, and the private sector in managing the village funds. In addition to having reliable resources, universities and the private sector also have experience managing finance, programs, and program implementation.

\section{References:}

Anderson, J.R. 2003. Risk in Rural Development: Challenges for Managers and Policy Makers. Agricultural System, 75, 161-197.

Government Regulations No. 166 of 2014 on Poverty Alleviation Acceleration Program.

Government Regulations No. 22 of 2015 on Amandemen of Village Funds from National Budget.

Government Regulations No. 43 of 2014 on Villages.

Government Regulations No. 60 of 2014 on Village Funds Sourced from National Budget.

Government Regulations No. 78 of 2014 on Accelerated Development of Disadvantaged Areas.

Law No. 23 of 2014 on Local Government.

Law No. 6 of 2014 on Villages.

Marks, G., Hooghe, L., Blank, K. 1996. European Integration from the 1980s: State Centric vs. Multi-Level Governance. Journal of Common Market Studies, 34(3), 341-378.

Midmore, P. 1998. Rural Policy Reform and Local Development Programmes: Appropriate Evaluation Procedures. Journal of Agricultural Economics, 49(3), 409-426.

Palmer, C.F. 1984. Systems Analysis and Model Building Techniques in Rural Development. Project Management, 2(4), 232-239.

Secretary General Ministry of Village, Development of Disadvantaged Region, and Transmigration. 2018. Establishing Accountability on Village fund Utilization. Paper presented at Asian Association for Public Administration International Conference, Universitas Gadjah Mada, Yogyakarta, on March 22-23, 3-8. 